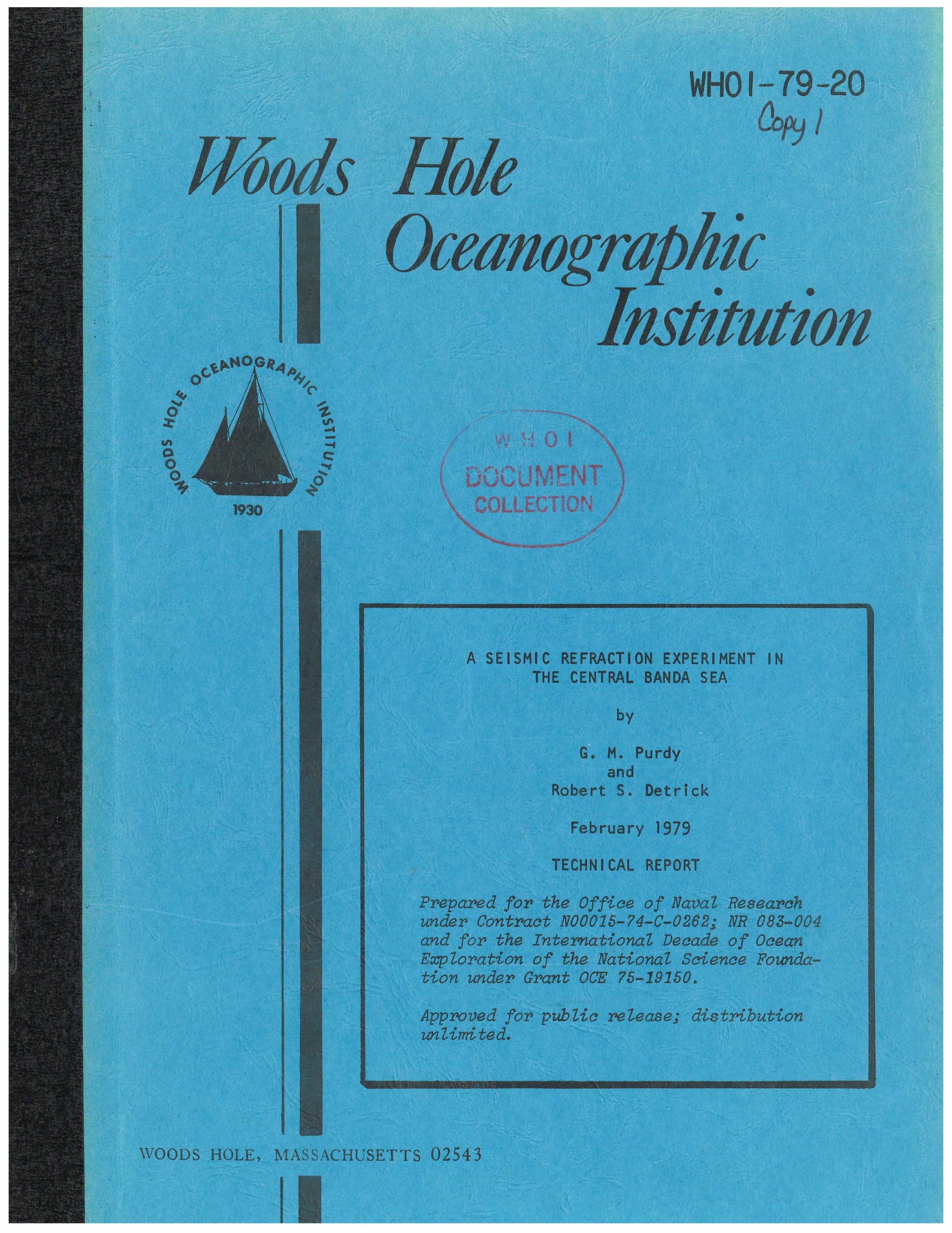


WHOI $-79-20$

\title{
A SEISMIC REFRACTION EXPERIMENT IN THE CENTRAL BANDA SEA
}

\author{
by \\ G. M. Purdy \\ and \\ Robert S. Detrick \\ WOODS HOLE OCEANOGRAPHIC INSTITUTION \\ Woods Hole, Massachusetts 02543 \\ February 1979
}

TECHNICAL REPORT

Prepared for the Office of Naval Research under Contract N00014-74-C-0262; NR 083-004 and for the International Decade of Ocean Exploration of the National Science Foundation under Grant OCE 75-19150.

Reproduction in whole or in part is permitted for any purpose of the United States Govermment. In citing this report in a bibliogrophy, the reference given should be to "Journal of Geophysical Research, Vol. 83, No. B5, May 10, 1978, pp. 2247-2257".

Approved for public release; distribution unZimited.

Approved for Distribution: John 1. Ewing, Chairman

Department of Geology \& Geophysics 


\title{
A Seismic Refraction Experiment in the Central Banda Sea
}

\author{
G. M. Purdy \\ Woods Hole Oceanographic Institution, Woods Hole, Massachusetts 02543 \\ Robert S. Detrick \\ Woods Hole Oceanographic Institution, Woods Hole, Massachusetts 02543 \\ Massachusetts Institute of Technology, Cambridge, Massachusetts 02139
}

\begin{abstract}
A seismic refraction experiment in the central Banda Sea is interpreted by using both slope intercept and delay time function methods. The crustal structure is shown to be oceanic, with velocities $(4.97,6.47$, 7.18 , and $7.97 \mathrm{~km} / \mathrm{s}$ ) typical of oceanic layers $2,3 \mathrm{~A}$, and $3 \mathrm{~B}$ and the mantle. Individual layer thicknesses vary systematically along the line, though the range of thicknesses observed for layers $2(1.5-2.0 \mathrm{~km})$ and $3 \mathrm{~A}(2.0-3.5 \mathrm{~km})$ falls well within the range observed for normal oceanic crust. Layer $3 \mathrm{~B}$ is unusually thick $(2.5-4.6 \mathrm{~km})$, the result being slightly greater than normal depths to Moho of 9-10 km below the sea floor. Shear head waves from layers $3 \mathrm{~A}$ and $3 \mathrm{~B}$ are identified on two receivers. In both cases, shear wave conversion occurred at the sediment/layer 2 interface. The observed shear wave velocities and intercepts indicate a Poisson's ratio of $0.25-0.28$ in layer 3 and $\sim 0.33$ in layer 2 . These and earlier results from the southern Banda basin indicate that the entire Banda Sea is underlain by oceanic type crust.
\end{abstract}

\section{INTRODUCTION}

The island arcs, trenches, and marginal basins of Indonesia form one of the most tectonically active and complex regions of the world. The Banda arc, in eastern Indonesia, is the apparent eastward continuation of the Sunda arc system, which separates the Indian-Australian plate from Eurasia [Fitch, 1972; W. Hamilton, 1973]. The Banda arc (Figure 1) consists of a volcanically active inner arc and an outer, nonvolcanic arc extending northeastward from Wetar and Timor through the Tanimbar and Aru islands around to Seram and Buru on the north. The inner and outer arcs are separated by the Weber Deep, a trough with depths in excess of $7 \mathrm{~km}$. Within the inner volcanic arc lies the Banda Sea, a marginal basin characterized by typical oceanic water depths (4-5 km), low uniform heat flow [Jacobson et al., 1977], and a relatively thin sediment cover $(<1 \mathrm{~km})$.

While the entire Sunda-Banda arc system is believed to have originated from the Cenozoic convergence of the Eurasian, Indian, and Pacific plates [Fitch, 1972], the nature of the crust within the Banda Sea and its tectonic evolution are not well understood. It is not known, for example, whether the Banda Sea is an active interarc basin of the type described by Karig [1971], an inactive one, or a trapped piece of older oceanic crust. The only published information on the crustal structure in the Banda Sea is from a single reversed refraction line shot in the early 1960's in the southern Banda basin (Figure 1). Results from this line indicate a typically oceanic crustal structure with a slightly shallower than normal depth to mantle [Curray et al., 1977]. It is important to determine whether this type of crust exists throughout the Banda Sea, and if not, where the major structural discontinuities are.

In this paper we describe a reversed refraction experiment carried out in the central Banda Sea during October 1976.

\section{DATA}

The receivers used were modified Select International SLF73 megahertz radio sonobuoys and the newly developed Woods Hole Oceanographic Institution ocean bottom hydrophone $(\mathrm{OBH})$ instrument. The line was oriented $\mathrm{N}-\mathrm{S}$ and was

Copyright (c) 1978 by the American Geophysical Union. approximately $74 \mathrm{~km}$ long (Figure 1). The OBH (OBH2) was deployed at the southern end of the line, a sonobuoy at the northern end (SB22), and a second sonobuoy (SB10) approximately midway between $\mathrm{OBH} 2$ and SB22.

A total of 68 shots were fired, ranging in size from 1 to 240 pounds. All travel times were corrected for the shot to ship travel time ('shot instant correction') and drift of the $\mathrm{OBH}$ chronometer relative to the shipboard master clock $(\sim 0.1 \mathrm{~ms} /$ h). Shot-receiver ranges were determined from direct and reflected water wave travel times. At $\mathrm{OBH} 2$, direct water waves were received at ranges out to $34 \mathrm{~km}$, but on the sonobuoy records, such arrivals were rarely received beyond $10 \mathrm{~km}$. Ranges were computed for the $\mathrm{OBH}$ water wave travel times and the sonobuoy first and second multiple reflected water wave travel times by using a sounding velocity of $1507 \mathrm{~m} / \mathrm{s}$ for the water column, as determined at nearby hydrographic stations. A near-surface water velocity of $1535 \mathrm{~m} / \mathrm{s}$ was used for the sonobuoy direct water wave arrivals.

The insert in Figure 1 shows that the two shooting runs were separated by $\sim 8 \mathrm{~km}$ owing to navigational inaccuracies. Initially, the data from these two subparallel lines were treated separately, but as no significant difference was seen between them, they were merged into a single data set.

Record sections were constructed for each receiver and used to pick refracted wave arrival times (Figures $2 a, 2 b$, and $2 c$ ). These travel times were corrected for water delay at both shot and receiver, the resulting data set of corrected travel times being as if all shots and receivers were on the sea floor. This data set was then interpreted by using both conventional slope intercept techniques and the delay time function method.

\section{ReCORd SECTIONS}

The record section for $\mathrm{OBH} 2$ (Figure $2 a$ ) shows clear first refracted arrivals out to ranges of $70 \mathrm{~km}$. The main refracted wave energy is generally concentrated in the first second after the first arrival, although there is considerable variation in the amplitude and character of these arrivals from shot to shot. The prominent second arrival, $\mathrm{G}^{\prime}$ in Figure $2 a$, is a reflection at the sea surface above the receiver.

The sonobuoy record sections (Figures $2 b$ and $2 c$ ) also show clear first arrivals at intermediate ranges. However, refracted 


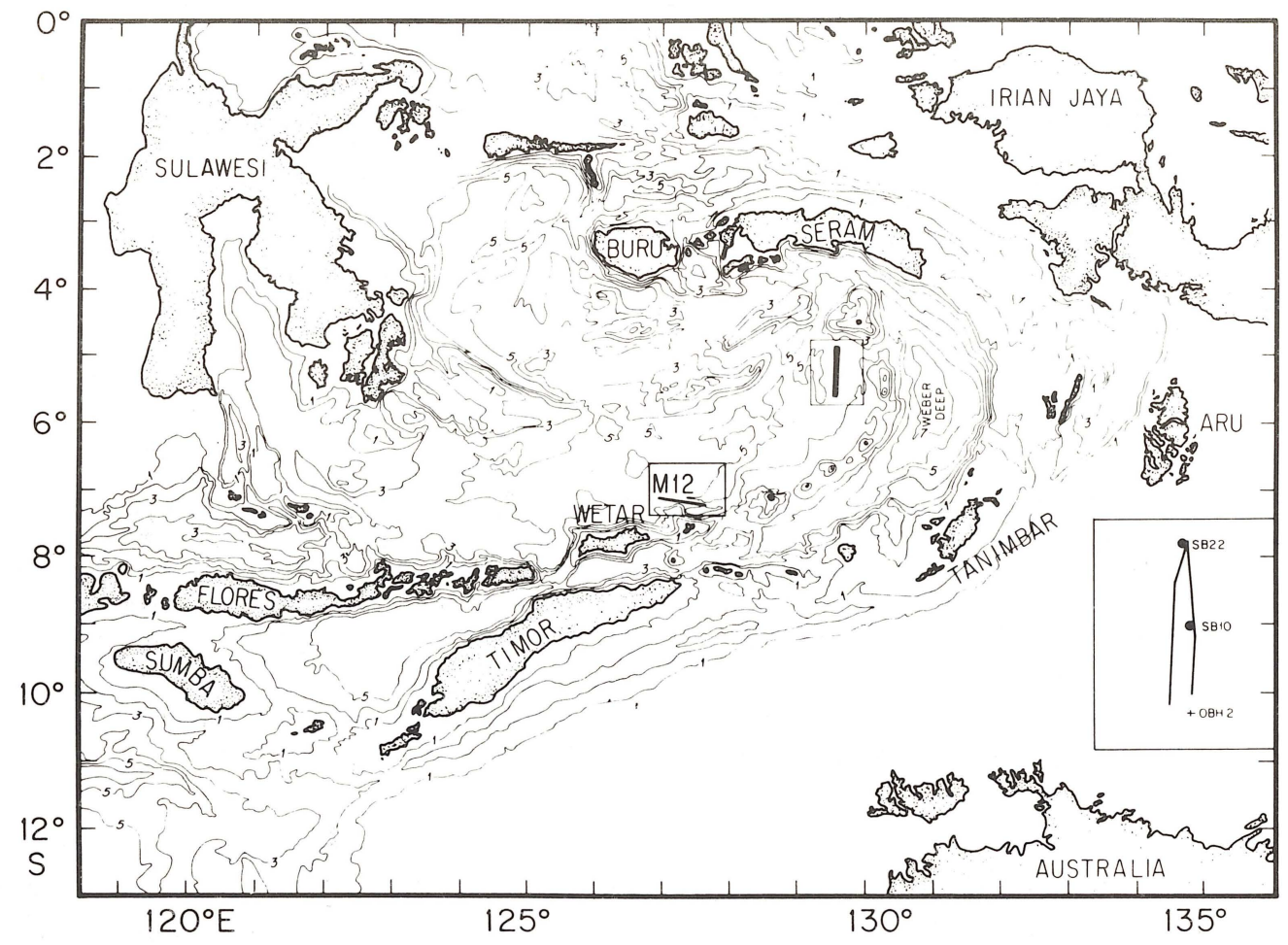

Fig. 1. The Banda Sea. The locations of the seismic refraction line reported in this paper (station 23) and of an earlier refraction line (M12) in the southern Banda Sea reported by Curray et al. [1977] are shown. Inset shows receiver locations and shooting lines for station 23. Bathymetry contour interval is $1 \mathrm{~km}$.

arrivals at ranges of less than $10 \mathrm{~km}$ are obscured by the water waves, and only weak first arrivals exist on SB22 beyond 50 $\mathrm{km}$. The character of the sonobuoy records at ranges less than $30 \mathrm{~km}$ differs markedly from the character of those at $\mathrm{OBH} 2$. The sonobuoy records show strong reverberations and the persistence of energy for many seconds after the first arrival, while at the $\mathrm{OBH}$, relatively little energy was received between the first arrival and the $G^{\prime}$ multiple.

A prominent second arrival $(P S P)$ is apparent on $\mathrm{OBH} 2$ between 6- and 10-s reduced travel time at ranges of $13-41 \mathrm{~km}$ and on SB22 between 12- and 15-s reduced travel time at ranges of $30-47 \mathrm{~km}$. Precise identification of the initial onset of this low-amplitude phase is difficult owing to interference from earlier arrivals. It is clearly visible, however, on shots 10731075 and 1084 on OBH2 and shots 1076 and 1079 on SB22 (Figures $2 a$ and $2 b$ ). Its apparent velocity of $3.6-3.9 \mathrm{~km} / \mathrm{s}$ suggests that it is a shear head wave propagating in layer 3 .

\section{SLOPE INTERCEPT INTERPRETATION}

Corrected time-distance graphs for the three receivers are shown in Figures $3 a, 3 b$, and $3 c$. The apparent velocities and intercepts are listed in Table 1.

Four apparent velocities are identified at $\mathrm{OBH} 2 ; 4.98,6.65$, 7.23 , and $8.08 \mathrm{~km} / \mathrm{s}$, which we associate with layers $2,3 \mathrm{~A}, 3 \mathrm{~B}$, and Moho, respectively. Both sonobuoys yield layer $3 \mathrm{~A}$ and $3 B$ type velocities, but only weak mantle arrivals were observed at SB22, and no layer 2 type velocities were identified at either sonobuoy. By using the layer 2 thickness determined at $\mathrm{OBH} 2$ (which is poorly constrained by only four first arrivals), simple calculations show that layer 2 refractions would not be observable as first arrivals at a sea surface receiver. In our structural interpretations we have therefore assumed that the $4.98-\mathrm{km} / \mathrm{s}$ layer 2 exists beneath both sonobuoys and have computed its thickness from the layer $3 \mathrm{~A}$ intercepts.
Sediment thickness and velocity are also poorly controlled. Although continuous air gun seismic reflection data were not obtained along the shooting line, reflection data obtained entering and leaving the area indicate a local sediment cover of about 0.5 -s two-way travel time. When a sediment velocity of $2.0 \mathrm{~km} / \mathrm{s}$ is assumed, the intercept of the $4.98-\mathrm{km} / \mathrm{s}$ layer at $\mathrm{OBH} 2$ is consistent with a sediment thickness of $0.77 \mathrm{~km}$. For lack of better information we assume a sediment layer of this thickness and velocity along the entire line.

Table 2 lists the true velocities and layer thicknesses obtained when $\mathrm{OBH} 2$ and $\mathrm{SB} 22$ are reversed. These velocities and layer thicknesses are typical of normal oceanic crust. The validity of this treatment is questionable, however, as the reverse points for the well-determined $3 \mathrm{~B}$ refractor disagree by $0.18 \mathrm{~s}$. This is a significant discrepancy considering the standard errors on the intercepts of these two segments, and it suggests that the requirement for planar interfaces is not satisfied. Additional control is provided by SB10, located midway along the line. The apparent velocities and intercepts of layers $3 \mathrm{~A}$ and $3 \mathrm{~B}$ at $\mathrm{SB} 10$ are significantly less than those observed at either end of the line. The reversed solution of SB10 and SB22 (Table 2) shows that the top of layer $3 \mathrm{~A}$ is shallower near the middle of the line and the computed dip, $1.8^{\circ}$ down to the north, is in the opposite direction to that computed by reversing $\mathrm{OBH} 2$ and $\mathrm{SB} 22$.

The structural solution most consistent with the observed apparent velocities and intercepts is shown by the dashed lines in Figure 4. A 1- to 2-km-thick layer 2 overlies a 2.5- to 3.0$\mathrm{km}$-thick layer $3 \mathrm{~A}$ with a velocity of $6.4 \mathrm{~km} / \mathrm{s}$. The layer 2/ layer $3 \mathrm{~A}$ interface is shallower beneath SB10 than at either end of the line, a fact that explains the lower apparent velocity observed for layer $3 \mathrm{~A}$ at SB10. Layer 3B, with a velocity of 7.1 $\mathrm{km} / \mathrm{s}$, is $2.7-3.9 \mathrm{~km}$ thick at either end of the line and appears to thicken beneath SB10. Mantle velocities of about $8.0 \mathrm{~km} / \mathrm{s}$ 


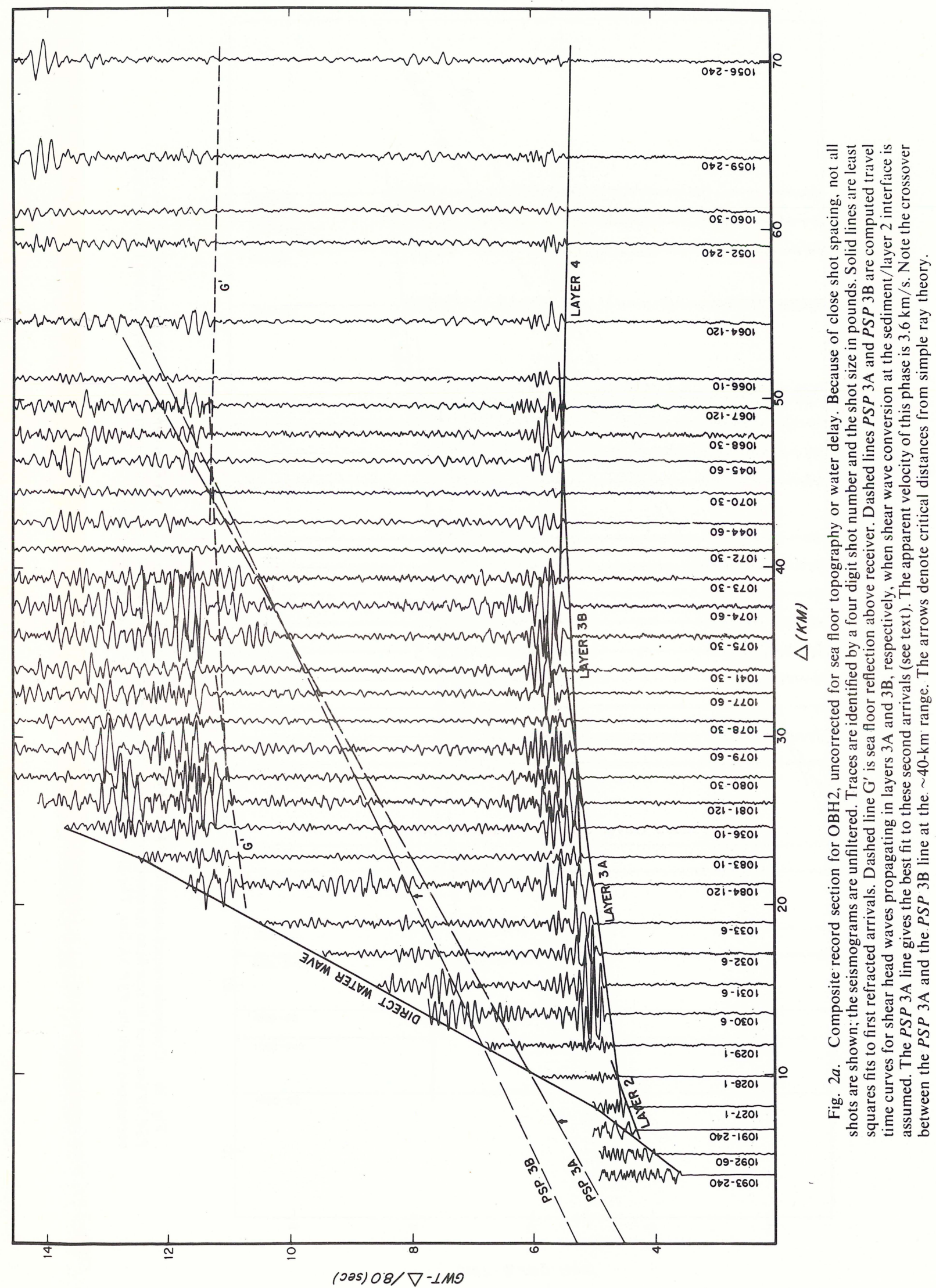




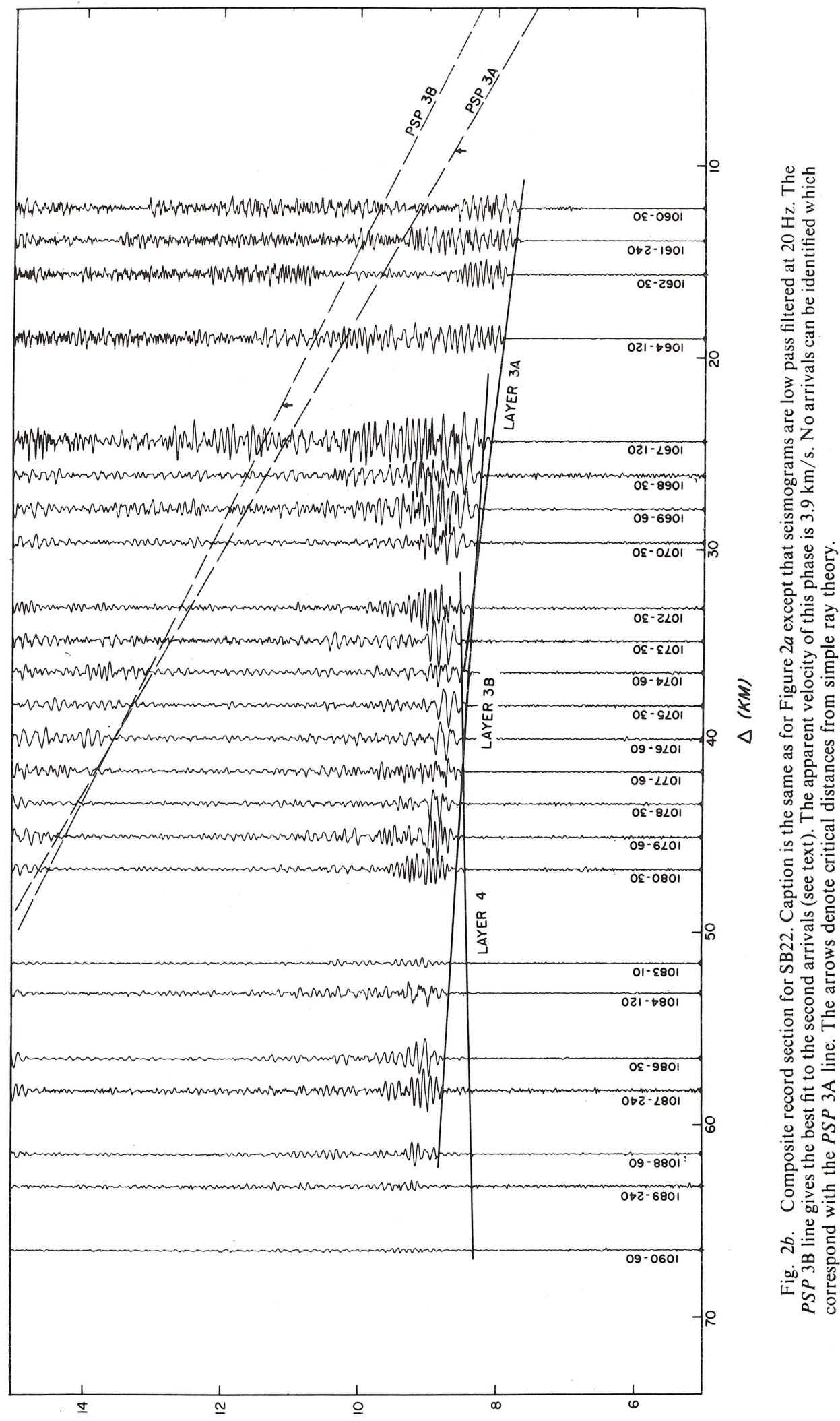

(025) $08 / \nabla-1 M 9$ 


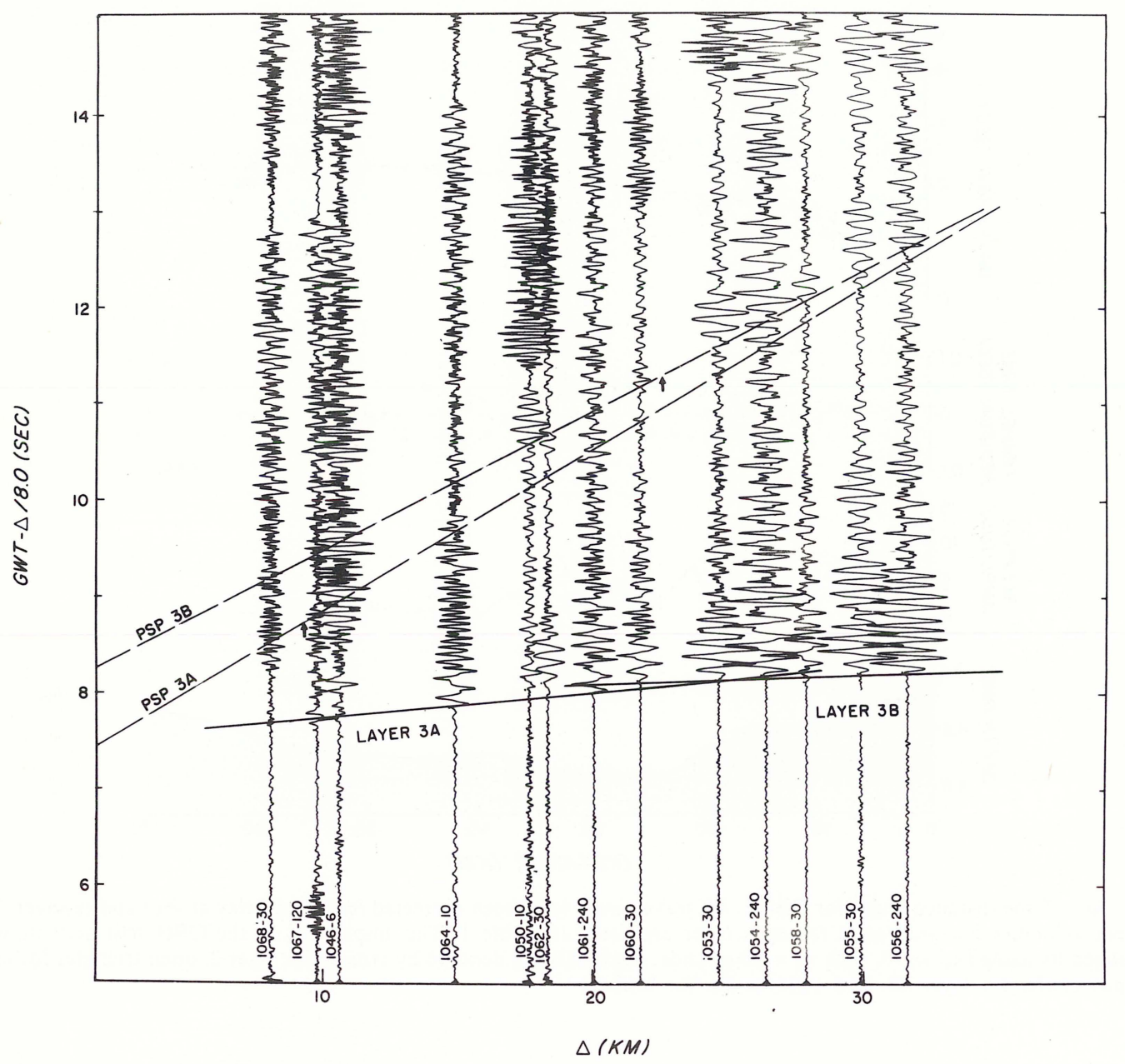

Fig. 2c: Composite record section for SB10. Caption is the same as for Figure $2 a$ except that seismograms are low pass filtered at $20 \mathrm{~Hz}$. The $P S P$ phases cannot be identified on this record section.

are present, and the depth to Moho varies between 9 and 10 $\mathrm{km}$ below the sea floor.

\section{Delay Time Function Inter pretation}

In order to better define the apparent undulations in the refracting interfaces suggested by the slope intercept interpretations, the delay time function technique [Morris et al., 1969; Raitt et al., 1969] was applied to these data. In this method the layer boundaries are not required to be planar surfaces but are allowed to undergo gentle undulations as described by low-order polynomial or Fourier functions of position. The general analytical procedure used was that described by Morris [1972].
Travel times from all receivers were combined into a single data set, and delay time surfaces of progressively higher order were calculated for layers $3 \mathrm{~A}$ and $3 \mathrm{~B}$, and the Moho. An increase in the number of terms in the polynomial expansion representing the delay time surface allows the surface to vary more rapidly and thus corresponds to more complicated structures. The time differences $R_{i}$ between observed travel times and solution-predicted travel times were used to calculate the standard error about the regression, $\sigma$, from

$$
\sigma=\sum_{i=1}^{n}\left[R_{i}^{2} /(N-M)\right]^{1 / 2}
$$

where $N$ is the number of observed travel times and $M$ is the

TABLE 1. Apparent Velocities, Intercepts, and Layer Thicknesses for Slope Intercept Solution

\begin{tabular}{|c|c|c|c|c|c|c|c|c|c|}
\hline \multirow[b]{2}{*}{ Layer } & \multicolumn{3}{|c|}{$\mathrm{OBH} 2$} & \multicolumn{3}{|c|}{ SB 10} & \multicolumn{3}{|c|}{ SB22 } \\
\hline & $\begin{array}{l}\text { Velocity, } \\
\mathrm{km} / \mathrm{s}\end{array}$ & $\begin{array}{l}\text { Intercept, } \\
\mathrm{s}\end{array}$ & $\begin{array}{c}\text { Thickness, } \\
\text { km }\end{array}$ & $\begin{array}{l}\text { Velocity, } \\
\mathrm{km} / \mathrm{s}\end{array}$ & $\begin{array}{l}\text { Intercept } \\
\mathrm{s}\end{array}$ & $\begin{array}{c}\text { Thickness, } \\
\text { km }\end{array}$ & $\begin{array}{c}\text { Velocity, } \\
\mathrm{km} / \mathrm{s}\end{array}$ & $\begin{array}{l}\text { Intercept, } \\
\mathrm{s}\end{array}$ & $\begin{array}{c}\text { Thickness, } \\
\text { km }\end{array}$ \\
\hline 1 & $(2.00)$ & $(0.00)$ & 0.77 & $(2.00)$ & $(0.00)$ & 0.77 & $(2.00)$ & $(0.00)$ & 0.77 \\
\hline 2 & $4.98 \pm 0.20$ & $0.71 \pm 0.07$ & 2.18 & $(4.98)$ & $(0.71)$ & 1.14 & $(4.98)$ & $(0.71)$ & 1.77 \\
\hline $3 \mathrm{~A}$ & $6.65 \pm 0.07$ & $1.32 \pm 0.03$ & 3.05 & $6.23 \pm 0.12$ & $1.01 \pm 0.05$ & 2.59 & $6.55 \pm 0.16$ & $1.20 \pm 0.07$ & 3.08 \\
\hline $3 \mathrm{~B}$ & $7.23 \pm 0.05$ & $1.74 \pm 0.04$ & 3.87 & $6.91 \pm 0.15$ & $1.42 \pm 0.08$ & & $6.99 \pm 0.05$ & $1.57 \pm 0.05$ & 2.74 \\
\hline 4 & $8.08 \pm 0.13$ & $2.44 \pm 0.12$ & & & & & $7.84 \pm 0.16$ & $2.17 \pm 0.13$ & \\
\hline
\end{tabular}

Values are determined by least squares regression of the travel time picks shown in Figures $3 a, 3 b$, and $3 c$. Parentheses indicate assumed velocities and intercepts. 

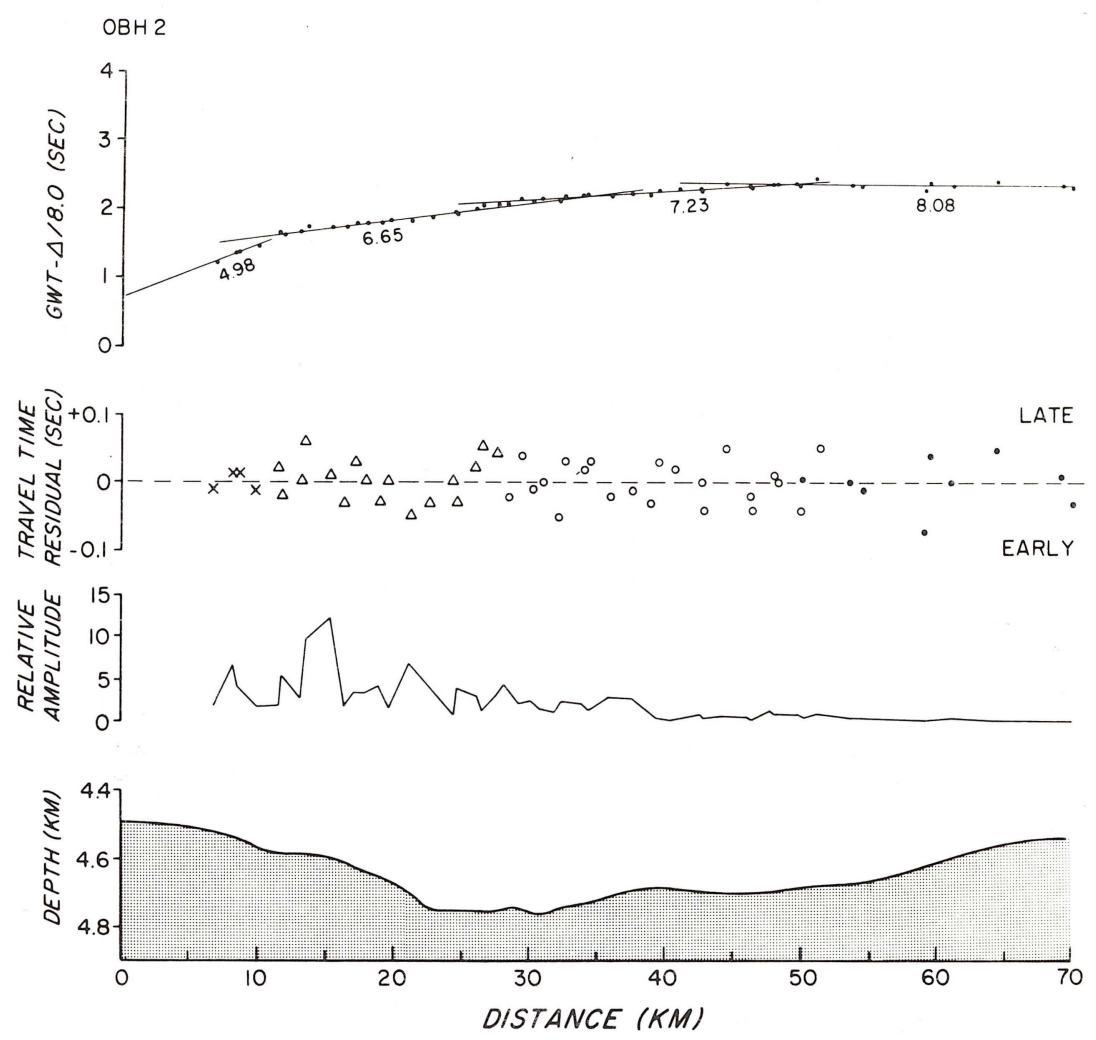

Fig. 3a. Time-distance graph for $\mathrm{OBH} 2$. All travel times have been corrected for water delay at shot and receiver. The apparent velocities and intercepts for each layer are listed in Table 1. The amplitudes of the OBH first arrivals were normalized by using $\left(w_{0} / w\right)^{0.65}$, with $w_{0}=30$ pounds. Residuals are denoted by crosses for layer 2 , open triangles for layer $3 \mathrm{~A}$, open circles for layer $3 \mathrm{~B}$, and solid circles for Moho.
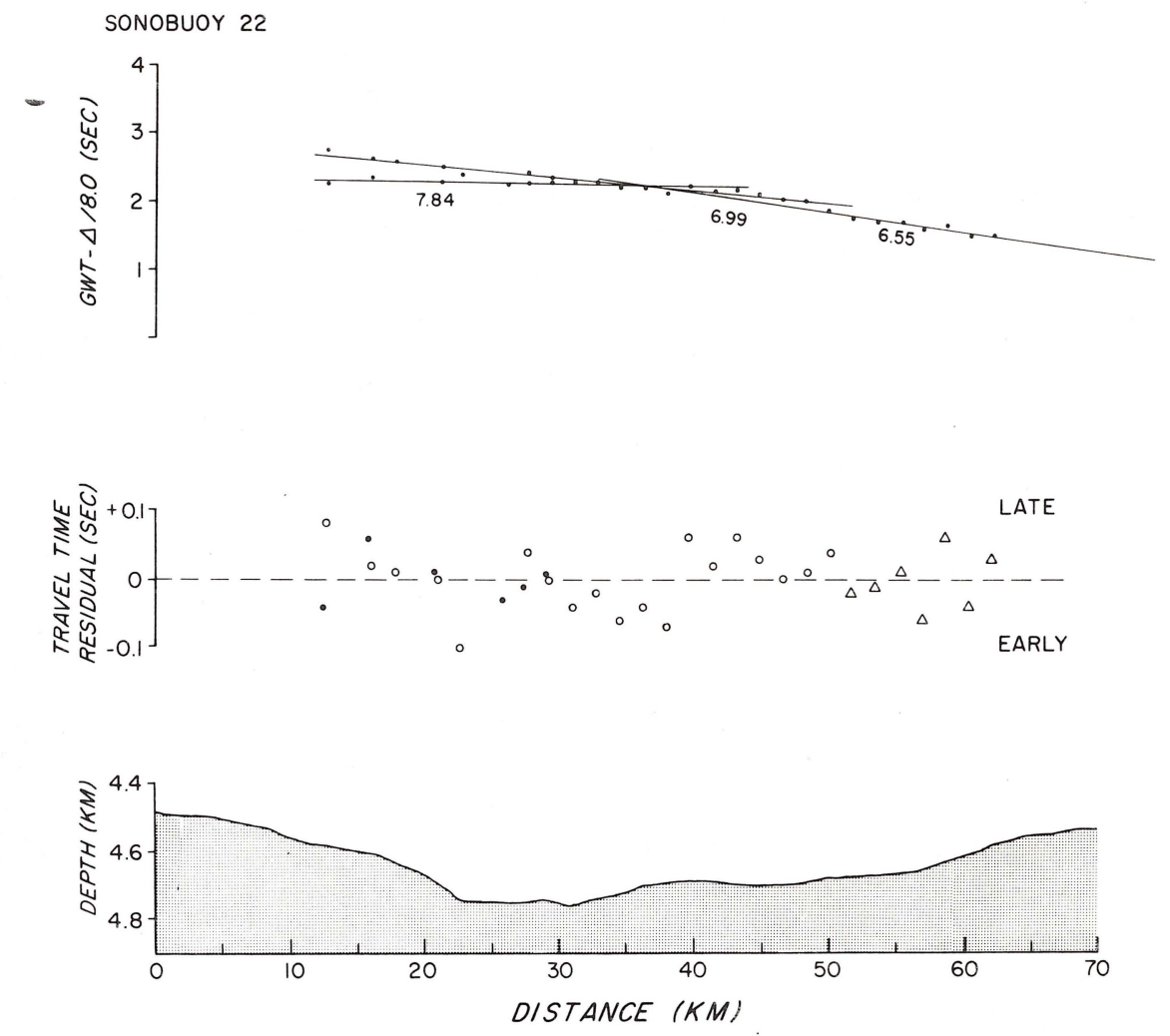

Fig. 3b. Time-distance graph for sonobuoy SB22. Caption is the same as for Figure $3 a$. 

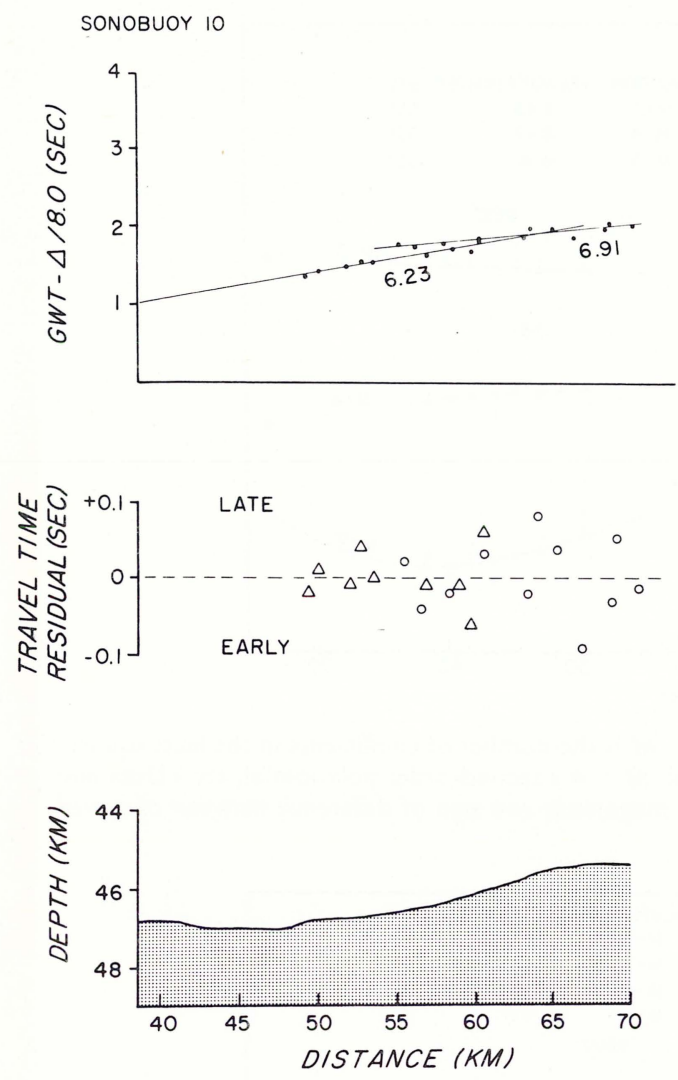

Fig. 3c. Time-distance graph for sonobuoy SB10. Caption is the same as for Figure $3 a$.

total number of coefficients in the least squares solution [Morris, 1972]. The quantity $\sigma$ indicates the overall quality of the fit and was used to judge whether higher-order polynomials significantly improved the solution. In this treatment we have assumed lateral and vertical velocity homogeneity within layers.

A comparison of the delay time surfaces computed for each layer is shown in Figures $5 a, 5 b$, and $5 c$. The first-order polynomial solution $(M=3)$ for layer $3 \mathrm{~A}$, which corresponds to a simple plane layer solution, shows large negative travel time residuals $\left(R<R_{\text {calc }}\right)$ at SB10 and large positive residuals $(R>$ $R_{\text {calc }}$ ) for the same shots at SB22 (Figure $5 a$ ). This is consistent with our earlier observation that the intercept of layer $3 \mathrm{~A}$ is less at SB10 than at SB22. The second-order polynomial solution $(M=4)$ reduces the standard error about the regression from 0.055 to $0.036 \mathrm{~s}$, and the travel time residuals show no systematic variation from receiver to receiver or shot to shot.

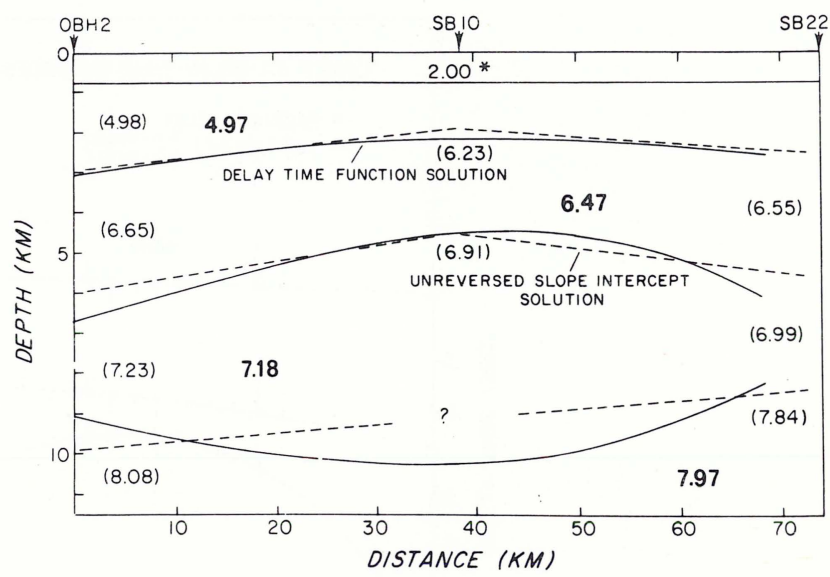

Fig. 4. Depth section based on unreversed slope intercept interpretation (dashed lines) and delay time function method (solid lines). All depths are below the sea floor. The thickness $(0.77 \mathrm{~km})$ and velocity $(2.0 \mathrm{~km} / \mathrm{s})$ of the sediment layer are assumed. Apparent velocities at each receiver are shown in parentheses. Delay time solution velocities are shown in boldface numbers.

The delay time surface bows gently upward: the delay time at SB10 is about $0.1 \mathrm{~s}$ less than at either end of the line. The solution velocity $(6.47 \mathrm{~km} / \mathrm{s})$ is intermediate between that determined by reversing $\mathrm{OBH} 2 / \mathrm{SB} 22$ and SB10/SB22. The next higher-order solution $(M=5)$ reduces the standard error slightly; however, we do not believe that the shot and receiver coverage for arrivals from this layer is adequate to justify this higher-complexity solution.

The delay time surface for layer $3 \mathrm{~B}$ is well determined by over 50 travel time observations (Figure $5 b$ ). Again, large systematic residuals exist for the lowest-order solution $(M=$ 3 ), positive for $\mathrm{OBH} 2$ and $\mathrm{SB} 22$ and negative for SB10. Higher-order solutions are significantly better fits to the data, and standard errors are reduced from 0.060 to $0.042 \mathrm{~s}$. Because of the large number of travel times the higher-order solutions are stable; there is almost no difference between the third- and fourth-order polynomial representations of the delay time surface $(M=5$ and 6 in Figure $5 b)$. Like that of layer $3 \mathrm{~A}$ the delay time surface of layer 3B bows upward, with delay times $\sim 0.2 \mathrm{~s}$ less beneath SB10 than at either end of the line.

A delay time surface has also been computed for the Moho (Figure 5c); however, because so few mantle arrivals were observed and since they are only associated with shots at either end of the line, the solution is limited to a first-order polynomial (equivalent to a reversed slope intercept solution of $\mathrm{OBH} 2$ and $\mathrm{SB} 22$ ).

TABLE 2. True Velocities and Layer Thicknesses Determined by Reversing OBH2/SB22 and SB22/SB10

\begin{tabular}{|c|c|c|c|c|c|c|c|c|}
\hline \multirow[b]{2}{*}{ Layer } & \multicolumn{4}{|c|}{$\mathrm{OBH} 2 / \mathrm{SB} 22$} & \multicolumn{4}{|c|}{ SB $10 / \mathrm{SB} 22$} \\
\hline & $\begin{array}{c}\text { Velocity, } \\
\mathrm{km} / \mathrm{s}\end{array}$ & $\begin{array}{c}\text { OBH2 } \\
\text { Thickness, } \\
\text { km }\end{array}$ & $\begin{array}{c}\text { SB22 } \\
\text { Thickness, } \\
\text { km }\end{array}$ & $\begin{array}{l}\text { Dip, } \\
\text { deg }\end{array}$ & $\begin{array}{l}\text { Velocity, } \\
\mathrm{km} / \mathrm{s}\end{array}$ & $\begin{array}{c}\text { SB } 10 \\
\text { Thickness, } \\
\text { km }\end{array}$ & $\begin{array}{c}\text { SB22 } \\
\text { Thickness, } \\
\text { km }\end{array}$ & $\begin{array}{l}\text { Dip, } \\
\text { deg }\end{array}$ \\
\hline 1 & $(2.00)$ & 0.77 & 0.77 & 0 & $(2.00)$ & 0.77 & 0.77 & 0 \\
\hline 2 & 4.98 & 2.21 & 1.75 & 0.50 & $(4.98)$ & 1.09 & 1.85 & 1.79 \\
\hline $3 \mathrm{~A}$ & 6.60 & 3.24 & 2.89 & 1.15 & 6.38 & 3.03 & 2.52 & 3.30 \\
\hline $3 B$ & 7.11 & 3.55 & 3.02 & 1.06 & 6.94 & & & \\
\hline 4 & 7.97 & & & & & & & \\
\hline
\end{tabular}

Parentheses indicate assumed velocities and intercepts. 


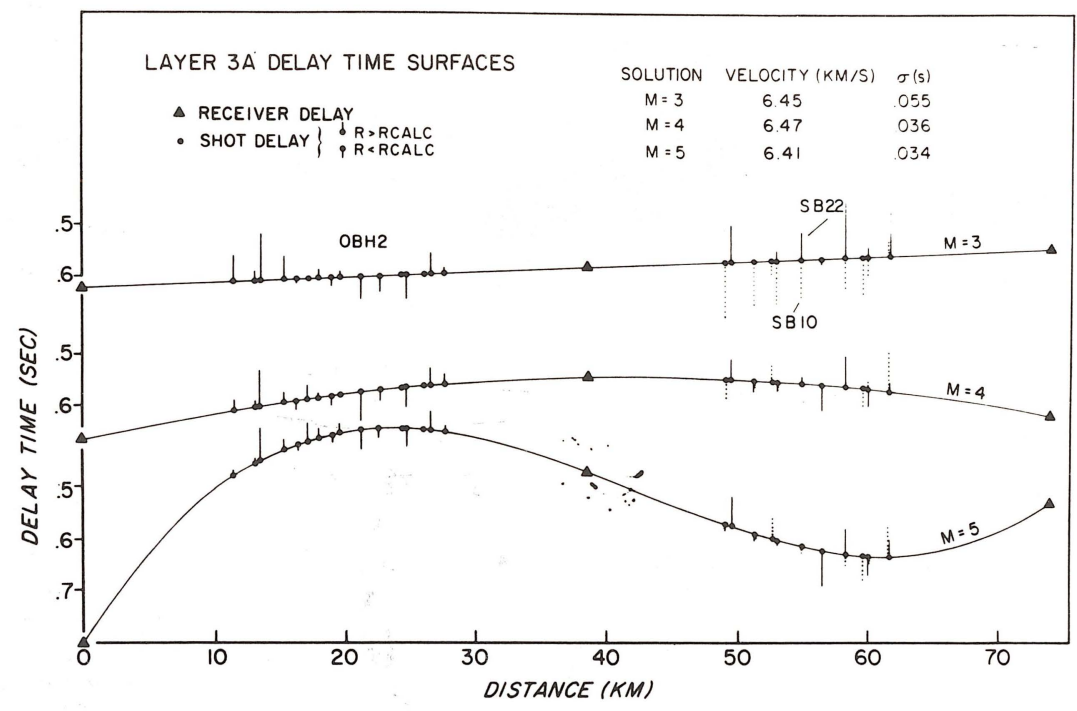

Fig. 5a. Delay time surfaces for different values of $M$ for layer 3A. $M$ is the number of coefficients in the least squares solution. (For example, $M=3$ corresponds to a first-order polynomial, $M=4$ a second-order polynomial, etc.) Dots and triangles show locations of shots and receivers. Vertical bars indicate magnitude and sign of difference between observed travel times and solution-predicted travel times.

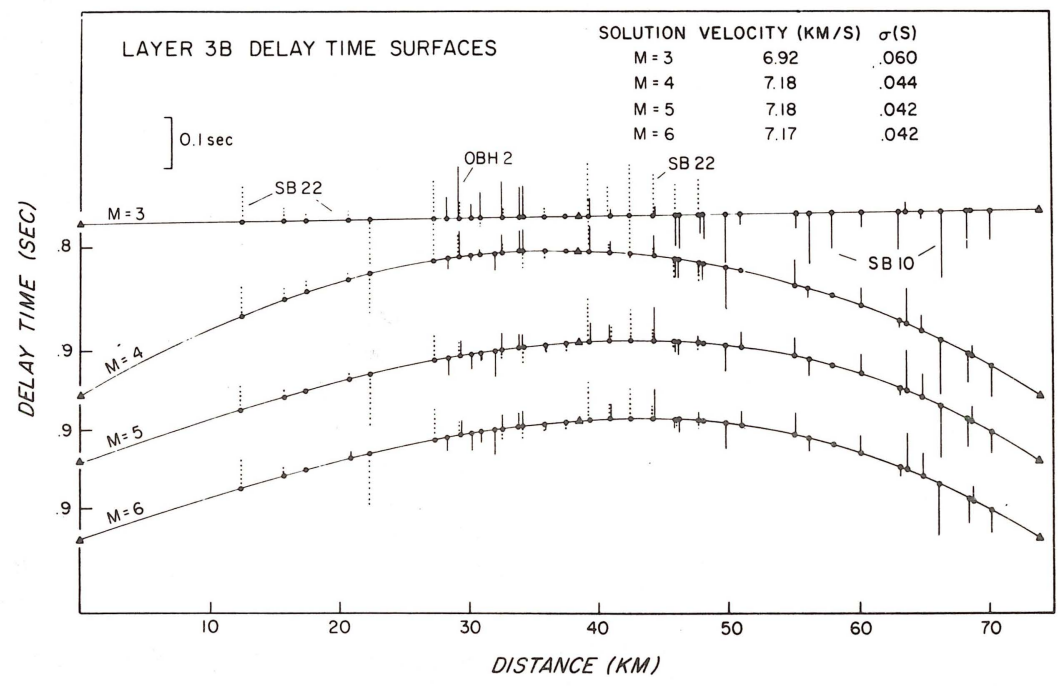

Fig. 5b. Delay time surfaces for different values of $M$ for layer 3B. Caption is the same as for Figure $5 a$.

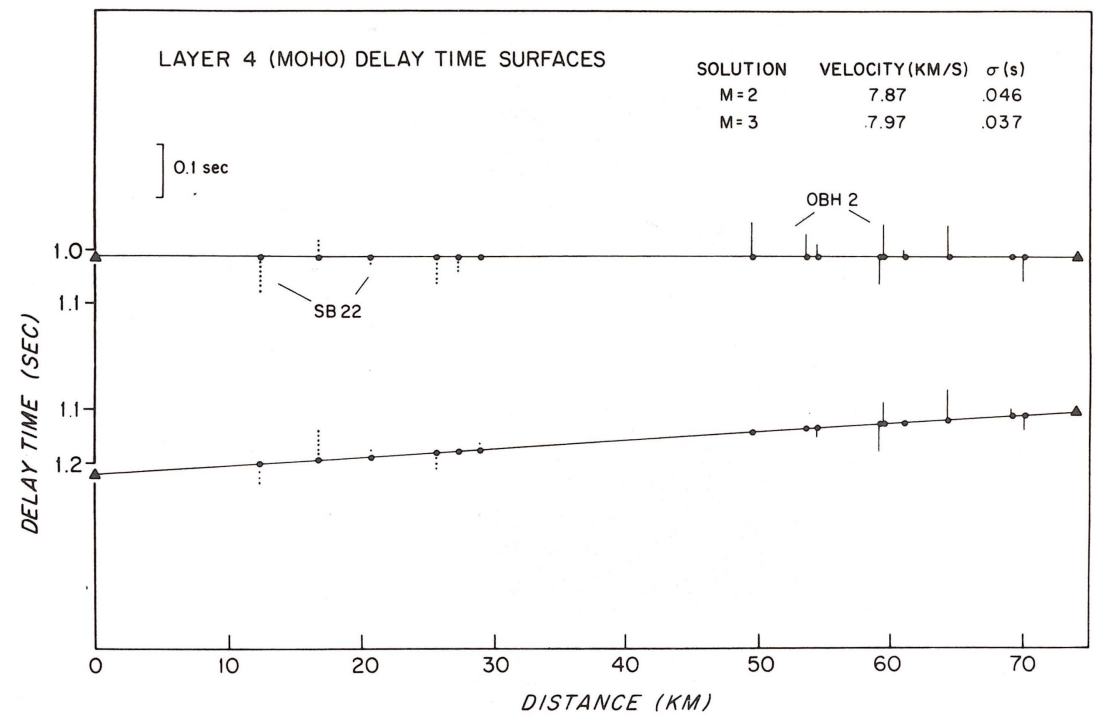

Fig. 5c. Delay time surfaces for different values of $M$ for the Moho. Caption is the same as for Figure $5 a$. 
These delay times may be converted into depths if the velocities and delay time surface of the overlying crustal layers are known. $Z_{n}(x)$, the depth to the $n$th layer, is

$$
Z_{n}(x)=\sum_{i=1}^{n-1} \tau_{i}(x) V_{i}\left(1-V_{i}^{2} / V_{n}^{2}\right)^{-1 / 2}
$$

where $\tau_{i}(x)$ is the delay time and $V_{i}$ is the velocity of the $i$ th layer.

Using the velocities and delay time surfaces computed for layers $3 \mathrm{~A}(M=4)$ and $3 \mathrm{~B}(M=6)$ and the mantle $(M=3)$, we have computed a depth section. As was done in the slope intercept interpretation, we have assumed the existence of a sediment layer $0.77 \mathrm{~km}$ thick with a velocity of $2.0 \mathrm{~km} / \mathrm{s}$ overlying a $4.98-\mathrm{km} / \mathrm{s}$ layer of variable thickness. These assumptions naturally introduce some uncertainty into our solution. The resulting depth section is shown in Figure 4 superimposed on the unreversed slope intercept interpretation.

There is good agreement between these two structural solutions, particularly for the well-determined layer 2/layer $3 \mathrm{~A}$ and layer $3 \mathrm{~A} /$ layer $3 \mathrm{~B}$ interfaces. They indicate that the top of layer $3 \mathrm{~A}$ is $\sim 1 \mathrm{~km}$ shallower and the top of layer $3 \mathrm{~B}$ is $\sim 2.5$ $\mathrm{km}$ shallower beneath SB10 than at either end of the line. This structural solution is consistent with the observed apparent velocities for layers $3 \mathrm{~A}$ and $3 \mathrm{~B}$, which are lower at SB10 than at the other two receivers. The most striking feature of the delay time solution is the thickening of layer $3 \mathrm{~B}$ from less than $2.5 \mathrm{~km}$ beneath $\mathrm{OBH} 2$ and SB22 to almost $6 \mathrm{~km}$ beneath SB 10 . The thickness of this layer depends, of course, on the depth to Moho, which is not well constrained, particularly beneath SB10 (Figure 5c). However, the low apparent mantle velocities observed at both SB22 (7.84) and OBH2 (8.08) require the dip of the layer $3 \mathrm{~B} / \mathrm{mantle}$ interface to be in the opposite sense of the dip of the shallower layer 2/layer $3 \mathrm{~A}$ and layer $3 \mathrm{~A} /$ layer $3 \mathrm{~B}$ interfaces. Consequently, layer $3 \mathrm{~B}$ must thicken from about $2.5 \mathrm{~km}$ to probably $4-6 \mathrm{~km}$ beneath SB10, and the depth to Moho is probably not shallower than $9-10 \mathrm{~km}$ below the sea floor anywhere along this line.

\section{PSP PHASE}

The structural solution shown in Figure 4 can be used to examine the origin of the PSP phase identified at $\mathrm{OBH} 2$ and SB22 (Figures $2 a$ and $2 b$ ). The apparent velocities and intercepts of these phases are poorly constrained by the data. The apparent velocity of this phase on $\mathrm{OBH} 2$ is about $3.6 \mathrm{~km} / \mathrm{s}$, consistent with propagation as a shear head wave in layer $3 \mathrm{~A}$. However, on SB22 the apparent velocity is significantly higher: about $3.9 \mathrm{~km} / \mathrm{s}$. The intercepts also differ, being about $0.84 \mathrm{~s}$ larger at SB22 than at $\mathrm{OBH} 2$ (after the $\mathrm{OBH}$ intercept has been corrected to the sea surface). There is no corresponding difference between $\mathrm{OBH} 2$ and SB22 in apparent velocities or intercepts of the layer $3 \mathrm{~A} P$ wave arrivals (Table 1). Thus we conclude that we are observing two different phases: a shear head wave propagating in layer $3 \mathrm{~A}$ on $\mathrm{OBH} 2$ and a shear head wave propagating in a deeper layer, probably layer $3 \mathrm{~B}$, on SB22.

We have computed model time-distance curves for these phases using a simplified version of the structural solution shown in Figure 4 and the apparent velocities of 3.6 and 3.9 $\mathrm{km} / \mathrm{s}$ determined from the record sections (Figures $2 a$ and $2 b$ ). In making these calculations we assumed that $P$ to $S$ conversion took place at the sediment/layer 2 interface beneath the shot and $S$ to $P$ conversion at that same interface beneath the receiver.
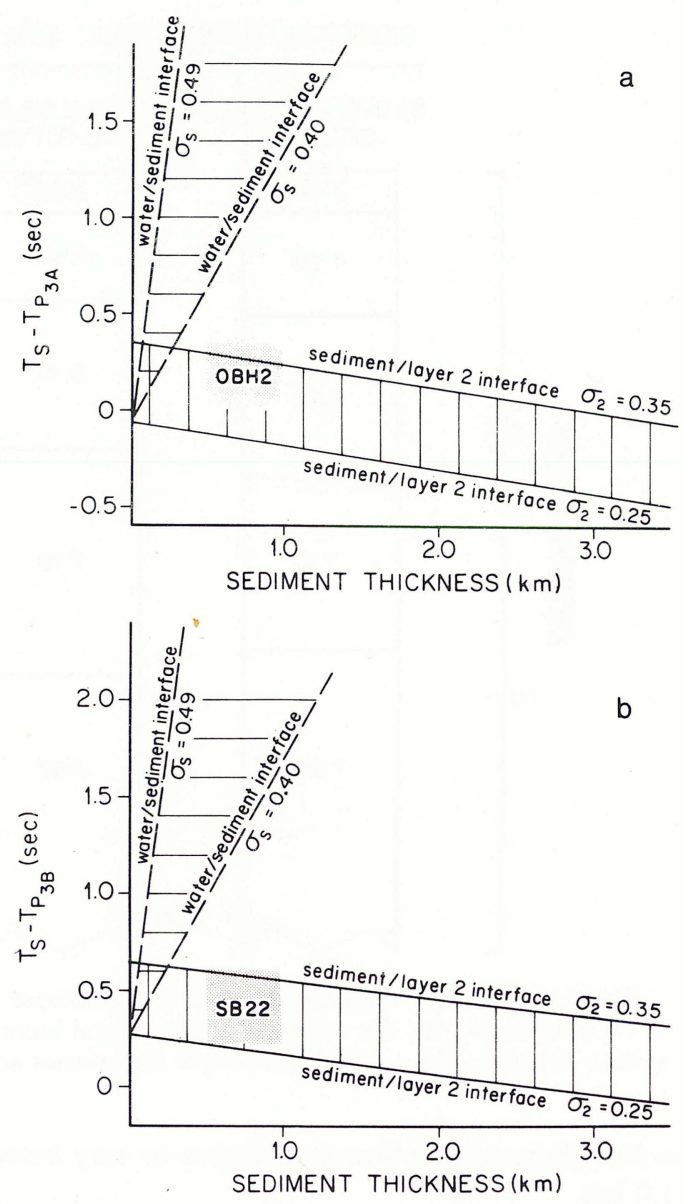

Fig. 6. (a) Computed differences in intercept time $\left(T_{S}-T_{P}\right)$ of $P$ and $P S P$ phases propagating through layer $3 \mathrm{~B}$ with shots and receivers corrected to the sea surface. These differences were computed for various sediment thicknesses by using a simplified version of the crustal model shown in Figure 4 and reasonable values of Poisson's ratio (see text). The solid lines are for shear wave conversion at the sediment/layer 2 interface, and the dashed lines are for conversion at the water/sediment interface. Poisson's ratio in layer 2 is $\sigma_{2}$, and Poisson's ratio in the sediments is $\sigma_{s}$. The shaded square shows the observed limits of observed intercept time difference and sediment thickness for $\mathrm{OBH} 2$. This figure together with Figure $6 b$ shows that shear wave conversion must take place at or near the sediment/layer 2 interface. $(b)$ Computed differences in intercept time $\left(T_{S}-T_{P}\right)$ of $P$ and $P S P$ phases propagating through layer $3 \mathrm{~B}$ with shots and receivers corrected to the sea surface. The shaded square shows the observed limits of observed intercept time difference and sediment thickness for SB22.

This assumption is justified by a study of differences in intercept time between the PSP phases and the corresponding compressional wave arrivals. The magnitude and sign of this time difference depend upon where shear wave conversion occurs. Figures $6 a$ and $6 b$ show the computed differences in intercept time $\left(T_{S}-T_{P}\right)$ between shear and compressional waves refracted in layer 3A (Figure 6a) and layer 3B (Figure $6 b)$.

$T_{S}-T_{P}$ is plotted against sediment thickness and for reasonable limiting values of Poisson's ratio $\sigma:(1)$ in the sediments, $\sigma_{s}=0.40-0.49$ [Sutton et al., 1971; E. L. Hamilton et al., 1970; Davis et al., 1976], and (2) in layer 2, $\sigma_{2}=0.25-0.35$ [Francis, 1976; Christensen, 1972]. In these figures the shaded box shows the observed differences in intercept time between the $P S P$ and the $P$ phase for SB22 (Figure $6 b$ ) and OBH2 (Figure $6 a$ ). Study of seismic reflection data close to this 
CENTRAL BANDA SEA STA 23

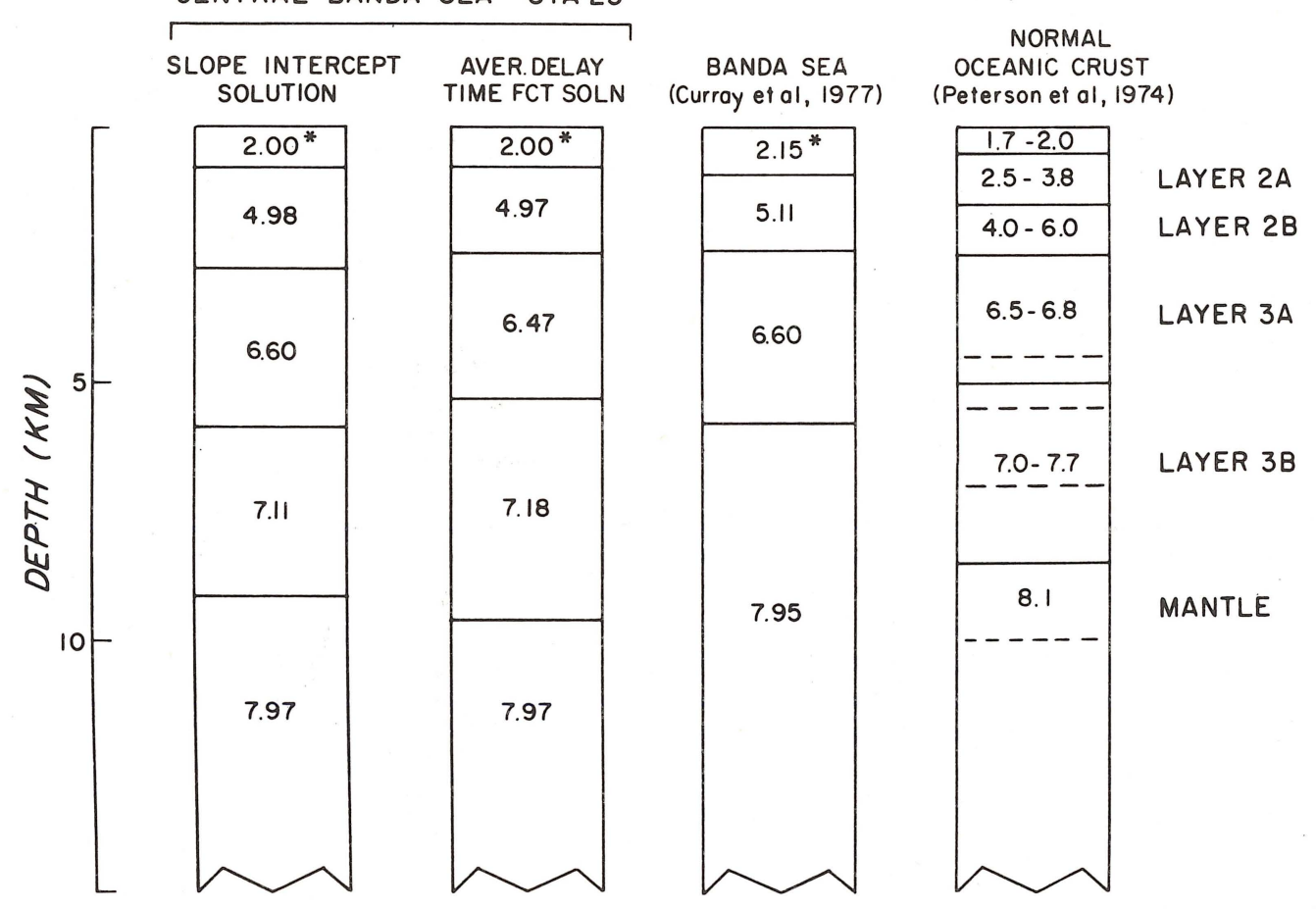

Fig. 7. Summary of crustal structures determined from this experiment and the southern Banda Sea [Curray et al., 1977] compared with the normal oceanic crustal section of Peterson et al. [1974]. Average delay time function solution section calculated by averaging the layer thicknesses at $10-\mathrm{km}$ intervals along the line.

refraction line shows the sediment thickness to vary between 0.5 and $1.0 \mathrm{~km}$.

The intercept of the PSP phase at OBH2 (corrected to the sea surface) is $7.4 \mathrm{~s}$, about $0.2 \pm 0.2 \mathrm{~s}$ greater than the intercept of the $6.5-\mathrm{km} / \mathrm{s} P$ wave arrival (see shaded box in Figure $6 a$ ). This figure shows that this observed difference in intercept time cannot be explained by $P$ to $S$ conversion at or close to the water/sediment interface but is in good agreement with the model involving $\boldsymbol{P}$ to $S$ conversion at the sediment/layer 2 boundary. The same conclusion is reached from study of Figure $6 b$ showing the calculated and observed $T_{S}-T_{P}$ for the layer 3B PSP shear head wave recorded at SB22.

Thus the model time-distance curves for the PSP arrivals shown in Figures $2 a$ and $2 b$ were computed on the assumption that conversion took place at the sediment/layer 2 interface. A Poisson's ratio of 0.33 in layer 2 gave a reasonable fit to the seismograms for the layer $3 \mathrm{~A} P S P$ curve on OBH2 (Figure 2a) and the layer 3B PSP curve on SB22 (Figure $2 b$ ).

For a surface receiver the crossover distance for layer $3 \mathrm{~A}$ and layer $3 \mathrm{~B} P S P$ waves is about $35 \mathrm{~km}$. Figure $2 b$ shows that on SB22 the layer 3A PSP phase is obscured at ranges less than $30 \mathrm{~km}$ by other unidentified high-amplitude arrivals. Thus on SB22, only the layer 3B PSP phase is observed.

For a sea floor receiver the crossover distance for layer $3 \mathrm{~A}$ and layer $3 \mathrm{~B} P S P$ waves is about $40 \mathrm{~km}$. Only the layer $3 \mathrm{~A}$ $P S P$, phase is observed on $\mathrm{OBH} 2$ because the $3 \mathrm{~B}$ phase at ranges greater than $40 \mathrm{~km}$ is masked by the sea surface reflection $\left(\mathrm{G}_{1}\right.$ in Figure $\left.2 a\right)$.

A noteworthy feature on the $\mathrm{OBH}$ record section is the large-amplitude PSP arrivals on shots 1073, 1074, and 1075. We suggest that this is due to either the onset of a Moho PSP phase (critical distance of $\sim 32 \mathrm{~km}$ ) or constructive interference between $3 \mathrm{~A}$ and $3 \mathrm{~B}$ PSP arrivals.

We conclude that the observed PSP phases suffered con- version at or near the sediment/layer 2 boundary, that the apparent shear wave velocities indicate Poisson's ratios of 0.25 and 0.28 in layers $3 \mathrm{~A}$ and $3 \mathrm{~B}$, and that the observed intercepts of both the $3 \mathrm{~A}$ and the $3 \mathrm{~B}$ PSP phase suggest a Poisson's ratio in layer 2 of about 0.33 .

\section{Discussion}

Our results from the central Banda Sea may be compared with those of Curray et al. [1977] from the southern Banda Sea and an 'average' oceanic crustal section (Figure 7). The shallow crustal structure determined in this study is almost identical to that reported by Curray et al. They, however, did not identify a $7.2-\mathrm{km} / \mathrm{s}$ refractor. This layer is often difficult to identify at surface receivers without close shot spacing [Sutton et al., 1971]. Since the shot spacing in the experiment reported by Curray et al. was about $3 \mathrm{~km}$, few first arrivals would be expected from this layer, and it could have been easily overlooked. This is particularly likely if the thickness of layer 3B were less in their area than in the central Banda Sea. The presence of an unidentified layer intermediate in velocity between the $6.6-\mathrm{km} / \mathrm{s}$ layer and the mantle would explain the slightly shallower than normal mantle depths determined for their experiment.

The results reported in this paper and those of Curray et al. [1977] indicate that the crust of the central and southern Banda Sea is typically oceanic in character, with velocities and layer thicknesses falling within the range of those given by Peterson et al. [1974] for layers 2B, 3A, and 3B for normal oceanic crust (Figure 7). The unusually thick layer $3 \mathrm{~B}$ observed in the central Banda Sea and the smaller thickness or absence of this layer in the southern Banda Sea suggest some local variability in crustal structure; however, there is no reason to suspect that this variability is any greater in the Banda Sea than elsewhere in the world's oceans. 


\section{CONCLUSIONS}

1. The crustal structure in the central Banda Sea is typically oceanic in character, with a well-developed basal oceanic layer (layer 3B) and normal mantle depths of 9-10 km below the sea floor.

2. Excellent agreement was found between the layer thicknesses and velocities determined by a traditional slope intercept solution and those calculated by using a multilayer generalization of the delay time function technique.

3. Prominent second arrivals apparent on both $\mathrm{OBH}$ and sonobuoy record sections have been identified as shear head waves propagating in layer $3 \mathrm{~A}(\mathrm{OBH} 2)$ and layer 3B (SB22). The difference in intercept time between these phases and the corresponding $P$ wave arrivals indicates that shear wave conversion occurred at the sediment/layer 2 interface. The shear wave velocities indicate normal Poisson's ratios of $0.25-0.28$ for layer 3; however, the shear wave intercepts require a significantly higher Poisson's ratio $(\sigma=0.33)$ in layer 2 .

Acknowledgments. This work was supported by the International Decade of Ocean Exploration office of the National Science Foundation under grant OCE 75-19150 and by the Office of Naval Research. We thank Russ Raitt for his computer programs and assistance with the delay time function technique. One author (R.S.D.) received partial support from the Woods Hole Oceanographic Institution Education Program. The design and construction of the ocean bottom hydrophone instruments were supported in part by the Ocean Industry Program of Woods Hole. We thank the officers, the crew, the scientific complement, and particularly the chief scientist, Carl Bowin, on board $\mathrm{R} / \mathrm{V}$ Atlantis II during cruise 93, leg 13, whose hard work and cooperation made this experiment possible. This manuscript benefited from critical reviews by J. I. Ewing, C. O. Bowin, and E. T. Bunce. Woods Hole Oceanographic Institution contribution 4047.

\section{REFERENCES}

Christensen, N. I., The abundance of serpentinites in the oceanic crust, J. Geol., 80, 709, 1972

Curray, J. R., G. G. Shor, Jr., R. W. Raitt, and M. Henry, Seismic refraction and reflection studies of crustal structure of the eastern Sunda and western Banda arcs, J. Geophys. Res., 82, 2479, 1977.
Davis, E. E., C. R. B. Lister, and B. T. R. Lewis, Seismic structure of the Juan de Fuca Ridge: Ocean bottom seismometer results from the median valley, J. Geophys. Res., 81, 3541, 1976.

Fitch, T. J., Plate convergence, transcurrent faults, and internal deformation adjacent to southeast Asia and the western Pacific, $J$. Geophys. Res., 77, 4432, 1972.

Francis, T. J. G., The ratio of compressional to shear velocity and rock porosity on the axis of the Mid-Atlantic Ridge, J. Geophys. Res., 81, 4361, 1976

Francis, T. J. G., and I. T. Porter, Median valley seismology: MidAtlantic Ridge near $45^{\circ}$ N, Geophys. J. Roy. Astron. Soc., 34, 279. 1973.

Hamilton, E. L., H. P. Burkel, P. O. Keir, and J. A. Whitney, Velocities of compressional and shear waves in marine sediments determined in situ from a research submersible, J. Geophys. Res., 75, 4039, 1970.

Hamilton, W., Tectonics of the Indonesian region, Geol. Soc. Malaysia Bull., 6, 3, 1973.

Jacobson, R. S., L. A. Lawver, K. Becker, and G. G. Shor, Jr., Anomalously uniform heat flow in the Banda Sea (abstract), Eos Trans. $A G U, 58,515,1977$.

Karig, D. E., Origin and development of marginal basins in the western Pacific, J. Geophys. Res., 76, 2542, 1971.

Morris, G. B., Delay-time-function method and its application to the Lake Superior refraction data, J. Geophys. Res., 77, 297, 1972.

Morris, G. B., R. W. Raitt, and G. G. Shor, Jr., Velocity anisotropy and delay-time maps of the mantle near Hawaii, J. Geophys. Res., $74,4300,1969$.

Peterson, J. J., P. J. Fox, and E. Schreiber, Newfoundland ophiolites and the geology of the oceanic layer, Nature, 247, 194, 1974.

Raitt, R. W., G. G. Shor, Jr., T. J. G. Francis, and G. B. Morris, A nisotropy of the Pacific upper mantle, J. Geophys. Res., 74, 3095, 1969.

Sutton, G. H., G. C. Maynard, and D. M. Hussong, Widespread occurrence of a high-velocity basal layer in the Pacific crust found with repetitive sources and sonobuoys, in The Structure and Physical Properties of the Earth's Crust, Geophys. Monogr. Ser., vol. 14 edited by J. G. Heacock, p. 193, AGU, Washington, D. C., 1971.

(Received November 1, 1977; revised January 13, 1978; accepted January 14, 1978.) 



\section{MANDATORY DISTRIBUTION LIST \\ FOR UNCLASSIFIED TECHNICAL REPORTS, REPRINTS, AND FINAL REPORTS PUBLISHED BY OCEANOGRAPHIC CONTRACTORS \\ OF THE OCEAN SCIENCE AND TECHNOLOGY DIVISION \\ OF THE OFFICE OF NAVAL RESEARCH}

(REVISED NOVEMBER 1978)

1 Deputy Under Secretary of Defense

(Research and Advanced Technology)

Military Assistant for Environmental Science

Room 3D129

Washington, D.C. 20301

Office of Naval Research

800 North Quincy Street

Arlington, VA 22217

3 ATTN: Code 483

1 ATTN: Code 460

2 ATTN: 102B

1 CDR J. C. Harlett, (USN)

ONR Representative

Woods Hole Oceanographic Inst.

Woods Hole, MA 02543

Commanding Officer

Naval Research Laboratory

Washington, D.C. 20375

6 ATTN: Library, Code 2627
12 Defense Documentation Center Cameron Station

Alexandria, VA 22314

ATTN: DCA

Commander

Naval Oceanographic Office NSTL Station

Bay St. Louis, MS 39522

1 ATTN: Code 8100

1 ATTN: Code 6000

1 ATTN: Code 3300

1 NODC/NOAA

Code D781

Wisconsin Avenue, N.W.

Washington, D.C. 20235 



\begin{tabular}{|c|c|}
\hline REPORT DOCUMENTATION PAGE & $\begin{array}{c}\text { READ INSTRUCTIONS } \\
\text { BEFORE COMPL,ETING FORM } \\
\end{array}$ \\
\hline $\begin{array}{l}\text { 9. REPORT NUMBER } \\
\text { WHOI }-79-20\end{array}$ & 3. RECIPIENT'S CATALOG NUMBER \\
\hline \multirow{2}{*}{$\begin{array}{l}\text { 4. TITLE (and Subtitio) } \\
\text { A SEISMIC REFRACTION EXPERIMENT IN THE CENTRAL } \\
\text { BANDA SEA }\end{array}$} & $\begin{array}{l}\text { 5. TYPE OF REPORT \& PERIOD COVERED } \\
\text { Technical }\end{array}$ \\
\hline & $\begin{array}{l}\text { 6. PERFORMING ORG. REPORT NUMBER } \\
\text { WHOI CON. NO. } 4047\end{array}$ \\
\hline $\begin{array}{l}\text { 7. AUTHOR(s) } \\
\text { G. M. Purdy and Robert S. Detrick }\end{array}$ & $\begin{array}{l}\text { 8. CONTRACT OR GRANT NUMBER(B) } \\
\text { NOOO14-74-C-0262; } \\
\text { OCE } 75-19150\end{array}$ \\
\hline $\begin{array}{l}\text { 9. PERFORMING ORGANIZATION NAME AND ADDRESS } \\
\text { Woods Hole Oceanographic Institution } \\
\text { Woods Hole, MA } 02543\end{array}$ & $\begin{array}{l}\text { 10. PROGRAMELEMENT, PROJECT, TASK } \\
\text { AREA \& WORK UNIT NUMBERS } \\
\text { NR } 083-004\end{array}$ \\
\hline \multirow{2}{*}{$\begin{array}{l}\text { 11. CONTROLLING OFF:CE NAME AND ADDRESS } \\
\text { NORDA } \\
\text { National Space Technology Laboratory } \\
\text { Bay St. Louis, MS } 39529\end{array}$} & $\begin{array}{l}\text { 12. REPORT DATE } \\
\text { February } 1979\end{array}$ \\
\hline & 13. NUMBER OF PAGES \\
\hline \multirow{2}{*}{ 14. MONITORING AGENCY NAME \& ADDRESS(It differont from Controlling Offico) } & $\begin{array}{l}\text { 15. SECURITY CLASS. (of this Poport) } \\
\text { Unclassified }\end{array}$ \\
\hline & $\begin{array}{l}\text { 15.. DECLASSIFICATION/DOWNGRADING } \\
\text { SCHEDULE }\end{array}$ \\
\hline
\end{tabular}

16. DISTRIBUTION STATEMENT (Of thIs RepOPt)

Approved for public release; distribution unlimited.

17. DISTRIBUTION STATEMENT (of the abstract entered in Block 20, If different from Report)

18. SUPPLEMENTAFY NOTES

Reprinted from "Journal of Geophysical Research, Vol. 83, No. B5, May 10, 1978, pp. 2247-2257".

19. KEY WOROS (Continuse on reverse sido if nocessary and ldentify by block number)

1. Refraction

2. Marginal Basin

3. Banda Sea

20. ADSTRACT (Continue on povergo wido if necoveary and Identlfy by block number)

A seismic refraction experiment in the central Banda sea is interpreted by using both slope intercept and delay time function methods. The crustal structure is shown to be oceanic, with velocities $(4.97,6.47,7.18$, and $7.97 \mathrm{~km} / \mathrm{s}$ ) typical of oceanic layers 2, $3 A$, and $3 B$ and the mantle. Individual layer thicknesses vary systematically along the line, though the range of thicknesses observed for layers $2(1.5-2.0 \mathrm{~km})$ and $3 A(2.0-3.5 \mathrm{~km})$ fall $\mathrm{s}$ well within the range observed for normal oceanic crust. Layer 3B (Cont. on back) 
is unusually thick $(2.5-4.6 \mathrm{~km})$, the result being slightly greater than normal depths to Moho of $9-10 \mathrm{~km}$ below the sea floor. Shear head waves from layers $3 A$ and $3 B$ are identified on two receivers. In both cases, shear wave conversion occurred at the sediment/layer 2 interface. The observed shear wave velocities and intercepts indicate a Poisson's ratio of $0.25-0.28$ in layer 3 and 0.33 in layer 2. These and earlier results from the southern Banda basin indicate that the entire Banda Sea is underlain by oceanic type crust. 


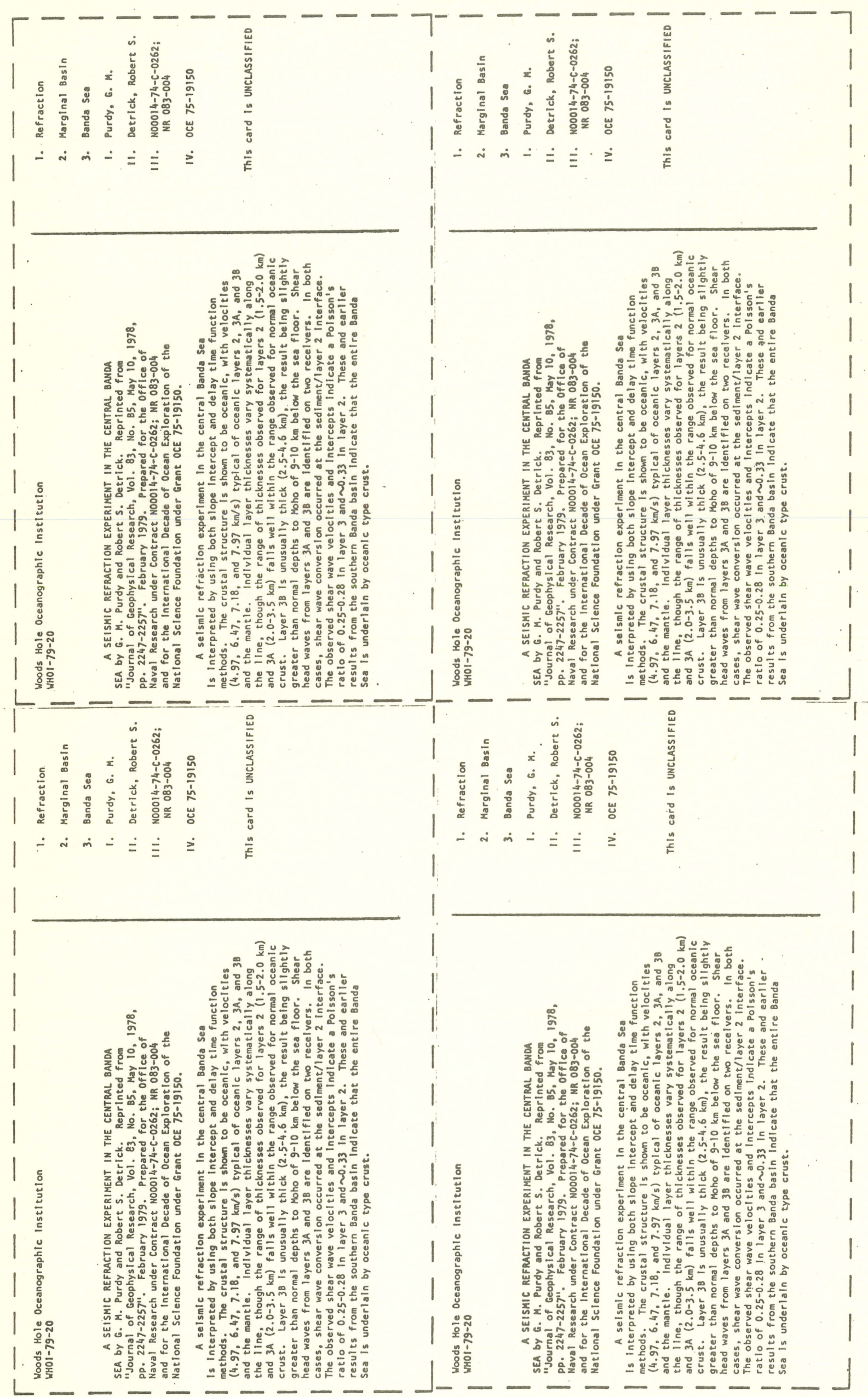

